\title{
The cycle of the seminiferous epithelium in the Japanese quail (Coturnix coturnix japonica) and estimation of its duration
}

\author{
M. Lin, R. C. Jones and A. W. Blackshaw* \\ Department of Biological Sciences, University of Newcastle, New South Wales 2308, Australia; and \\ * Department of Physiology and Pharmacology, University of Queensland, St Lucia, \\ Queensland 4067, Australia
}

\begin{abstract}
Summary. A regular, well defined spermatogenic cycle was found in the Japanese quail by examining thin sections of isolated lengths of seminiferous tubules embedded in epoxy resin to resolve the structure of developing spermatids. The stages of the cycle initially were identified in studies using a preparatory method for fixation which separated adjacent cellular associations. The cycle was divided into 10 stages with relative frequencies ( $\%$ ) of Stages I to X respectively of: $11 \cdot 9,14 \cdot 8,24 \cdot 1,10 \cdot 3,8 \cdot 2,6 \cdot 4,9 \cdot 4,5 \cdot 5,3 \cdot 8$ and 5.4. The duration of one cycle was $2.69 \pm 0.08$ days (mean \pm s.e.m.) as determined by intraventricular injection of $\left[{ }^{3} \mathrm{H}\right]$ thymidine and autoradiographic examination of the testes 1-4 days later. It was estimated that lifespans were 2.01 days for type B spermatogonia, 3.86 days for primary spermatocytes, 0.15 days for secondary spermatocytes, and 4.54 days for spermatids. The results suggest that the kinetics of spermatogenesis in the quail are fundamentally similar to the pattern in mammals.
\end{abstract}

Keywords: spermatogenesis; Japanese quail

\section{Introduction}

It has been known since late in the last century that the various generations of germ cells in the testes of mammals are not associated at random with a group of Sertoli cells, but form cellular associations and each association is constant (see Setchell, 1982, for review). Roosen-Runge \& Giesel (1950), Leblond \& Clermont (1952) and Ortavant (1954) arranged these cellular associations, or stages of the seminiferous epithelium, into an order and correctly predicted that the 4-5 generations of germ cells which are associated with a Sertoli cell sequentially develop through the stages. The period required to pass through all stages is considered to be one cycle of the seminiferous epithelium, and the number of cycles which occurs from an initial division of a stem spermatogonium to the release of its daughter spermatozoa into the lumen of the seminiferous tubule is determined by the number of generations of germ cells associated with a Sertoli cell. The value of recognizing the stages of the seminiferous epithelium and arranging them into an order is that it provides a basis for studying how spermatogenesis is regulated and for estimating the duration of spermatogenesis and the daily rate of sperm production of an animal.

However, there is no certainty that the accepted understanding of the process of spermatogenesis described above can be applied to birds. Although Clermont (1958) and Aire et al. (1980) identified 8 stages in the drake and guinea-fowl respectively, they reported that there were a large number of 'atypical' associations which they could not identify. Further, Yamamoto et al. (1967) concluded that the cellular associations are quite variable in the Japanese quail and described cellular associations (involving up to 3 generations of spermatids in one association) which are fundamentally different from the pattern in mammals. 
A major problem in determining the stages of the seminiferous epithelium in birds is that there may be a number of stages in one cross-section of a seminiferous tubule (e.g. 6-10 in the Japanese quail: Clermont, 1958; Yamamoto et al., 1967; Aire et al., 1980), and overlapping of germ cells in adjacent stages makes it difficult to resolve which generations of germ cells are all in one association. Moreover, the various steps of spermatid development in birds are not as easily recognized in paraffinwax sections as they are in eutherian mammals. We have solved these problems in the studies described in this report by examining thin sections of isolated tubules embedded in epoxy resin to resolve the structure of the developing acrosome in spermatids (Gunawardana, 1977), and by carrying out preliminary studies using a preparatory method for fixation which separated adjacent cellular associations. The report describes the stages of the seminiferous epithelium and estimates of the duration of a cycle of the seminiferous epithelium of the Japanese quail.

\section{Materials and Methods}

Adult, male Japanese quails $>48$ days old were used. Single seminiferous tubules were separated from the testicular parenchyma by using a hypodermic syringe mounted with a 23 -gauge needle to flush the testes with $1 \%$ (v/v) glutaraldehyde in $0 \cdot 1 \mathrm{~m}$-phosphate buffer ( $\mathrm{pH} 7 \cdot 2$ ). Lengths of 3-5 mm of a seminiferous tubule were cut from the anastomosing network of tubules, transferred into $3 \%(\mathrm{v} / \mathrm{v})$ glutaraldehyde in phosphate buffer and fixed overnight. The samples were post-fixed in 1\% osmium tetroxide and embedded in Spurr's resin (Agar Scientific Ltd, Stansted, Essex, UK) with one length of tubule in each block of resin. Sections 1-2 $\mu \mathrm{m}$ thick were cut on an Ultracut E ultramicrotome (Reichert-Jung, Wien, Austria) using glass knives, and stained with a solution containing $1 \%$ ( $/ / v)$ toluidine blue and $0.5 \%(\mathrm{w} / \mathrm{v})$ borax in $30 \%(\mathrm{v} / \mathrm{v})$ ethanol.

Initially the various stages of the seminiferous epithelium were identified with confidence due to the fortuitous finding that adjacent stages separated from one another when the seminiferous tubules were flushed apart with $0 \cdot 1 \mathrm{M}$ -

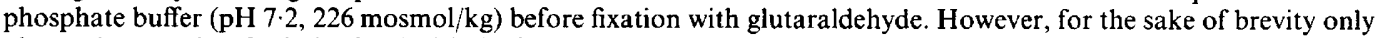
photomicrographs of tubules fixed with the flushing fluid are shown in this report as they showed the best preservation of the cytoplasm. Due to overlap between adjacent stages in the samples fixed with the flushing fluid some of the associations shown in Figs 1-10 were determined only after following the distribution of the Sertoli cell cytoplasm in the association in serial sections of the seminiferous tubule.

Seminiferous tubules from 4 animals were used to determine the frequency of each stage of the cycle of the seminiferous epithelium. Tubular cross-sections from 330 different tubules were examined (one section per tubule), and the only stages which were classified were those which possessed germ cells and a Sertoli cell in the section. The relative frequencies of the stages were calculated from the classification of 826 stages.

To determine the duration of a cycle of the seminiferous epithelium, 15 adult animals were injected intraventricularly with $\left[{ }^{3} \mathrm{H}\right]$ thymidine (Amersham Australia Pty Ltd, Sydney, Australia) at a rate of $1.5 \mu \mathrm{Ci} / \mathrm{g}$ body weight. Groups of 3 animals were killed at 2, 26, 50,74 and $98 \mathrm{~h}$ after injection, and samples of the testes were fixed, embedded, sectioned and stained as described above. For autoradiography the sections were coated with Ilford L4 bulk emulsion (Ilford Australia Pty Ltd, Waverley, Australia), exposed for 53 days and developed with Kodak Dektol developer (Kodak Australasia Pty Ltd, Coburg, Australia). Estimates of the duration of the cycle were calculated (Table 2) from determination of the most advanced labelled germ cells at each time after injection of the radioactive label (Clermont, 1972; Swierstra et al., 1974).

\section{Results}

\section{The cycle of the seminiferous epithelium}

Figure 12(a) illustrates the basis for the classification of germ cells into 3 types of spermatogonia, primary spermatocytes in meiotic phases, secondary spermatocytes and 12 steps of spermatid development. Figure 12(b) illustrates how the cycle of the seminiferous epithelium was divided into 10 stages, based on the morphology of the acrosome and nucleus of developing spermatids as described below.

Stage I (Fig. 1). Step 1 spermatids were a new generation of spermatids. They were characterized by a spherical nucleus with a narrow band of chromatin under the nuclear membrane and containing two, or more, centrally located, heavily stained chromatin bodies. Step 11 spermatids were clustered in groups embedded in Sertoli cell cytoplasm. They possessed long, cylindrical nuclei, 
and a large mass of cytoplasm extended towards the lumen of the seminiferous tubule. Primary spermatocytes in early pachytene were scattered between spermatids and spermatogonia. The nuclei of pachytene spermatocytes were larger than during other phases of spermatocyte development, and they contained thick chromatin strands twisted together. Three types of spermatogonia, dark type A, pale type $A$ and type B, were located on the basement membrane. Their cytoplasm was more intensely stained by toluidine blue than that of other kinds of germ cells. The pale type A spermatogonia had large, pale, round to ovoid nuclei with centrally located, intensely stained, chromatin particles consisting of 3-4 large clumps and some small clumps. The nuclei of dark type A spermatogonia were usually ovoid and darker and smaller than those of pale type A cells. Type B spermatogonia were distinguished by the presence of clumps of chromatin adhering to the nuclear membrane, and the density of staining of their nuclei was intermediate between that of dark and pale type A spermatogonia.

Stage II (Fig. 2). Step 2 spermatids contained a round nucleus with chromatin condensed into a large, centrally located mass, and one or two small, proacrosomic granules were located in the cytoplasm between the nuclear membrane and the plasmalemma. The other germinal cells were the same as in Stage I.

Stage III (Fig. 3). Step 3 spermatids had a round nucleus and were distinguished by the attachment of the acrosomic granule to the nuclear membrane. Type B spermatogonia were more active mitotically at this stage and some preleptotene primary spermatocytes were also present. The nuclei of the primary spermatocytes were larger and rounder than the nuclei of spermatogonia and their cytoplasm and chromatin (which was present as fine, evenly distributed granules) was less intensely stained. The other germ cells were similar to those in Stage II.

Stage IV (Fig. 4). Step 4 spermatids were distinguished by pale staining, centrally located chromatin particles in the nuclei, and the finely granular, almost uniform density of the chromatin. Step 12 spermatids showed a reduced amount of cytoplasm and well developed residual bodies. As well as the old primary spermatocytes in pachytene, a new generation of primary spermatocytes (from preleptotene to leptotene phases) were present. Dark and pale type A spermatogonia were observed on the basement membrane.

Stage $V$ (Fig. 5) corresponds to the period of spermiation. The step 5 spermatids had roughly spherical nuclei which stained homogeneously dark towards the end of the stage. The young primary spermatocytes were in zygotene, whilst the older primary spermatocytes and spermatogonia were the same as in Stage IV.

Stage VI (Fig. 6). Step 6 spermatids had a pear-shaped nucleus, and a small area of it was covered by the acrosome. The younger generation of spermatocytes developed into early pachytene whilst the older spermatocytes were in late pachytene or early diplotene. Dark type A spermatogonia remained the same as during Stage V, but some pale type A spermatogonia developed into metaphase of mitosis during the later part of the stage.

Stage VII (Fig. 7). Step 7 spermatids possessed elongated nuclei surrounded by considerable cytoplasm. Young spermatocytes remained in pachytene and the older spermatocytes entered diplotene. Type B spermatogonia were produced by the division of type A spermatogonia during this stage. Both dark and pale type A spermatogonia were located on the basement membrane.

Stage VIII (Fig. 8) was characterized by grouping the Step 8 spermatids which had longer, more cylindrical nuclei than Step 7 spermatids, and some centripetal migration of the cytoplasm which was destined to form residual bodies. The older spermatocytes were in diakinesis and the young spermatocytes and spermatogonia retained their Stage VII characteristics.

Stage IX (Fig. 9). The Step 9 spermatids were characterized by a reduced amount of cytoplasm at the rostral end of their nuclei and the formation of residual bodies by the cytoplasm around the middle of their nuclei. The old spermatocytes entered metaphase, then anaphase. The young spermatocytes and spermatogonia were similar to those in Stage VIII.

Stage $\boldsymbol{X}$ (Fig. 10). Step 10 spermatids were characterized by further elongation and condensation of their nuclei, displacement of their remaining cytoplasm to the most caudal end of the nucleus, 

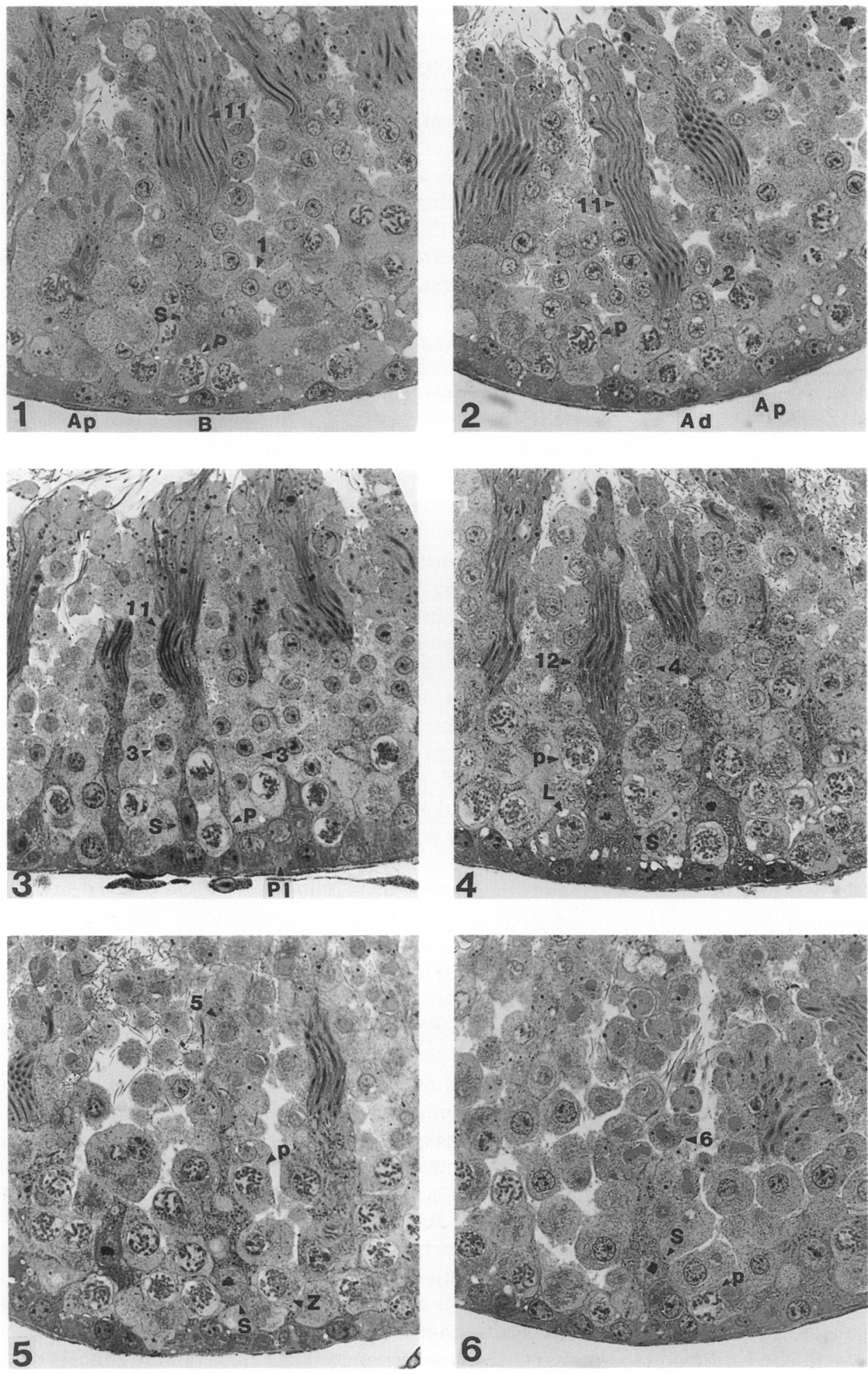

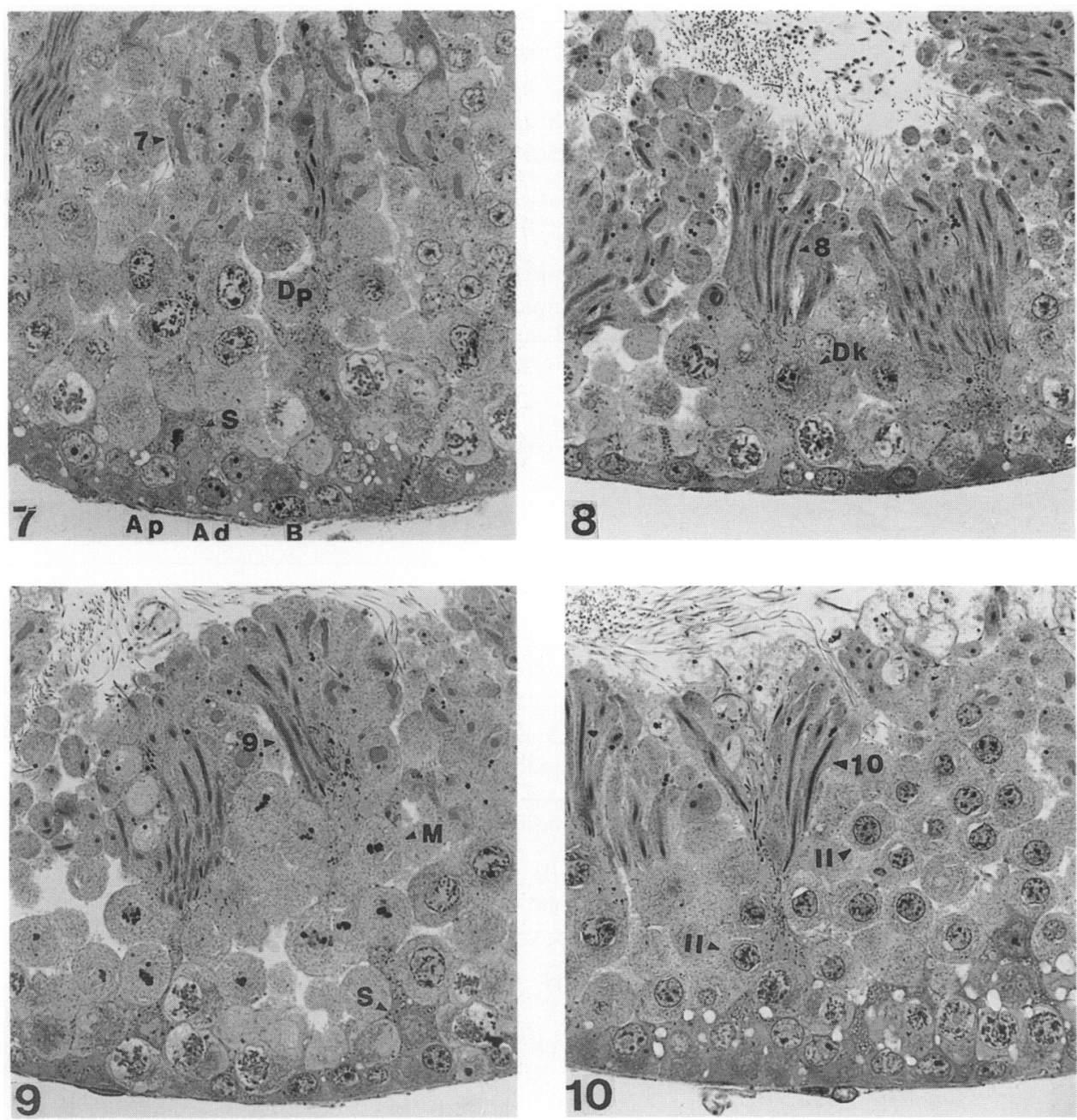

Figs 1-10. Photomicrographs of Stages I-X respectively of the cycle of the seminiferous epithelium in the Japanese quail. Numbers indicate steps of spermatid development; Ad, dark type A spermatogonia; Ap, pale type A spermatogonia; B, type B spermatogonia; L, leptotene primary spermatocytes: $\mathbf{Z}$, young primary spermatocytes in zygotene; $\mathbf{P}$, pachytene primary spermatocytes; M, older spermatocytes entering metaphase. II, secondary spermatocytes; $\mathrm{S}$, Sertoli cells. Spurr's resin, toluidine blue. $\times 1240$.

and the presence of secondary spermatocytes. The boundary of the nucleus of secondary spermatocytes was lined by intensely stained chromatin with several clumps protruding towards the centre of the nucleus. The secondary spermatocytes were easily distinguished from the newly forming Step 1 spermatids by the presence of clumps of chromatin lining the nuclear membrane. Pachytene spermatocytes and spermatogonia remained the same as in Stage IX.

\section{Frequency of the stages and duration of a cycle}

The frequencies of the 10 stages of the cycle are shown in Table 1. The findings relating to the incorporation of $\left[{ }^{3} \mathrm{H}\right]$ thymidine into germ cells are summarized in Table 2 . In the animals killed at the same time after injection there was no variation between animals in which germ cells were 
labelled. At $2 \mathrm{~h}$ after injection the most advanced labelled cells were leptotene primary spermatocytes at Stage IV (Fig. 11a). At 1 day after injection the labelled cells had progressed to pachytene primary spermatocytes at Stage VII. On Days 2 and 3 after injection the most advanced labelled cells were pachytene primary spermatocytes in Stage II and Stage V respectively. In samples taken 4 days after injection, the most advanced labelled cells were secondary spermatocytes in Stage $\mathrm{X}$ (Fig. $11 \mathrm{~b}$ ).

Table 1. Relative frequency (mean \pm s.d.) and duration of the stages of the cycle of the seminiferous epithelium in the Japanese quail $(\mathrm{N}=4)$

\begin{tabular}{|c|c|c|c|c|c|c|c|c|c|c|}
\hline & \multicolumn{10}{|c|}{ Stage } \\
\hline & I & II & III & IV & V & VI & VII & VIII & IX & $\mathrm{X}$ \\
\hline Frequency $(\%)$ & $\begin{array}{r}11.9 \\
\pm 3.1\end{array}$ & $\begin{array}{r}14.8 \\
\pm 5 \cdot 1\end{array}$ & $\begin{array}{r}24 \cdot 1 \\
\pm 3.9\end{array}$ & $\begin{array}{r}10 \cdot 3 \\
\pm 3 \cdot 4\end{array}$ & $\begin{array}{r}8.2 \\
\pm 1.4\end{array}$ & $\begin{array}{r}6.4 \\
\pm 0.5\end{array}$ & $\begin{array}{r}9.4 \\
+5.5\end{array}$ & $\begin{array}{r}5.5 \\
\pm 2.4\end{array}$ & $\begin{array}{r}3.8 \\
+1.5\end{array}$ & $\begin{array}{r}5.4 \\
\pm 0.8\end{array}$ \\
\hline Duration $(\mathrm{h})^{*}$ & $7 \cdot 7$ & $9 \cdot 5$ & $15 \cdot 5$ & $6 \cdot 6$ & $5 \cdot 3$ & $4 \cdot 1$ & $6 \cdot 1$ & $3 \cdot 6$ & $2 \cdot 5$ & $3 \cdot 5$ \\
\hline
\end{tabular}

*Based on the estimate of $64 \cdot 4 \mathrm{~h}$ for one cycle (see Table 2 ).

Table 2. Estimates of the duration of one cycle of the seminiferous epithelium in the Japanese quail

\begin{tabular}{|c|c|c|c|c|c|}
\hline \multirow{3}{*}{$\begin{array}{l}\text { Time }(\mathrm{h}) \text { after } \\
\text { injection of } \\
{\left[{ }^{3} \mathrm{H}\right] \text { thymidine }}\end{array}$} & \multicolumn{3}{|c|}{ Most advanced labelled cell } & \multirow{2}{*}{\multicolumn{2}{|c|}{ Duration of one cycle }} \\
\hline & & Cycle & No of cycles & & \\
\hline & Cell type & stage* & traversed & Days & Hours \\
\hline 2 & $\begin{array}{l}\text { Leptotene primary } \\
\text { spermatocyte }\end{array}$ & $2, \mathrm{IV}$ & - & - & - \\
\hline 26 & $\begin{array}{l}\text { Pachytene primary } \\
\text { spermatocyte }\end{array}$ & $2, \mathrm{VII}$ & 0.345 & $2 \cdot 90$ & $69 \cdot 6$ \\
\hline 50 & $\begin{array}{l}\text { Pachytene primary } \\
\text { spermatocyte }\end{array}$ & 3 , II & 0.759 & $2 \cdot 63$ & $63 \cdot 1$ \\
\hline 74 & $\begin{array}{l}\text { Pachytene primary } \\
\text { spermatocyte }\end{array}$ & $3, \mathrm{~V}$ & $1 \cdot 187$ & $2 \cdot 53$ & $60 \cdot 7$ \\
\hline 98 & $\begin{array}{l}\text { Secondary } \\
\text { spermatocyte }\end{array}$ & $3, \mathrm{X}$ & 1.493 & $2 \cdot 68$ & $64 \cdot 3$ \\
\hline Mean \pm s.e. & & & & $2 \cdot 69 \pm 0.08$ & $64.4 \pm 1.88$ \\
\hline
\end{tabular}

*No difference found among the animals within each group.

Table 2 shows that there was less than $9 \mathrm{~h}$ difference between the shortest and longest estimate of the duration of one cycle of the seminiferous epithelium with a mean \pm s.e.m. of $2.69 \pm 0.08$ days or $64 \cdot 4 \pm 3 \cdot 19 \mathrm{~h}$ (12 animals). As there are $3 \cdot 12$ cycles of the seminiferous epithelium between DNA synthesis of primary spermatocytes and spermiation of mature spermatozoa (Fig. 12b), it was estimated that the period between these events is 8.39 days. The duration of the spermatogonial division cannot be estimated in this study, because the process of renewal of the spermatogonia has not been determined.

Based on the duration of one cycle and the frequencies of the 10 stages, it was estimated that the lifespan of type B spermatogonia was 2.01 days, of primary spermatocytes was 3.86 days, of secondary spermatocytes was $0 \cdot 15$ days and of spermatids was 4.54 days. 

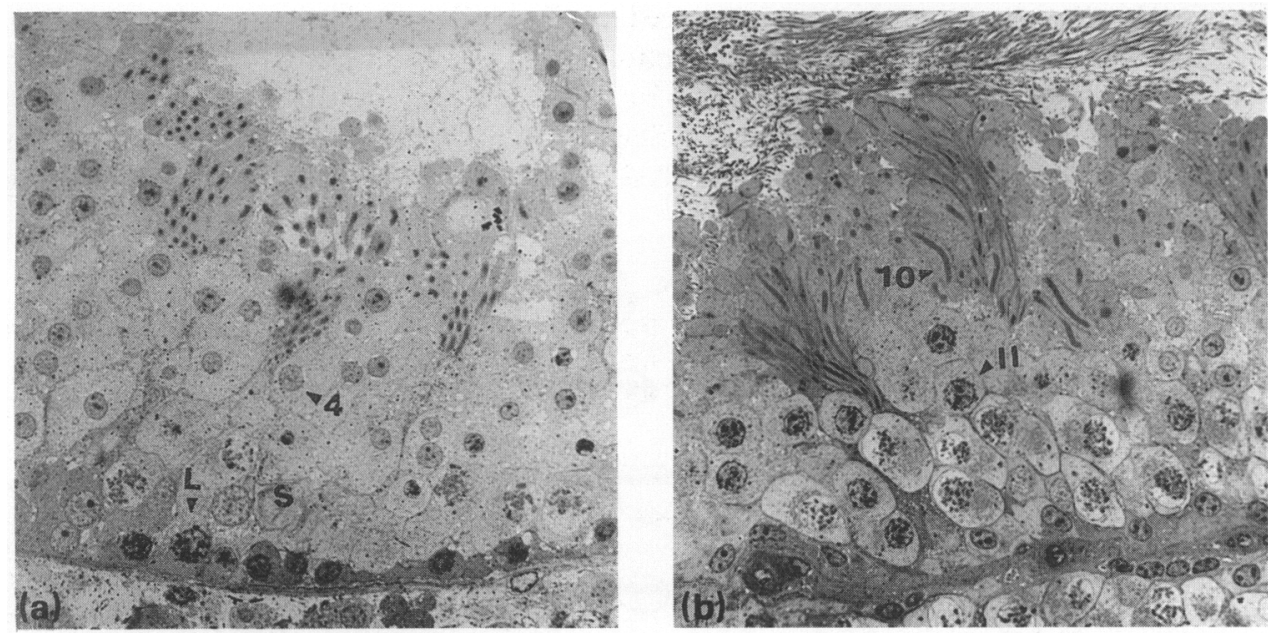

Fig. 11. Autoradiographs showing silver grains on (a) leptotene primary spermatocytes at Stage IV of the cycle, $2 \mathrm{~h}$ after $\left[{ }^{3} \mathrm{H}\right]$ thymidine injection (L) and (b) secondary spermatocytes in Stage $\mathrm{X}$, 4 days after injection (II). S. Sertoli cell; 4 , step 4 spermatid; 10 , step 10 spermatid. $\times 1240$.

\section{Discussion}

This study showed that it is possible to identify a regular, well defined cycle of the seminiferous epithelium in the Japanese quail, and that the cycle may be divided into 10 stages according to the developmental state of the acrosome (Leblond \& Clermont, 1952) and the nuclear morphology of the spermatids (Roosen-Runge \& Giesel, 1950; Ortavant, 1954). Further, the arrangement of germ cells in the associations of the seminiferous epithelium of the quail is not fundamentally different from the arrangement in the therian mammals which have been studied. The reasons why it was possible to identify the various cellular associations in this study were: (1) the finding that they separated from one another when flushed apart with phosphate buffer before fixation; (2) the preparation of thin epoxy resin sections which gave sufficient resolution to identify the developing acrosome of the spermatids and the extent of Sertoli cells; and (3) the isolation of lengths of the anastomosing network of seminiferous tubules so that an association could be easily traced in serial sections of a tubule.

The cycle of the seminiferous epithelium of the quail described in this study is different from that described by Yamamoto et al. (1967) who studied paraffin-wax sections and identified only 8 stages of the cycle. In their study, the arrangement of germ cells in the associations of the seminiferous epithelium were quite different from those described in mammals. For example, Stages IV to VIII contained up to 11 types of germ cells, including 3 generations of spermatids, and secondary spermatocytes were present in 6 stages of the cycle. Consequently, they concluded that: "It is likely that the spermatogenesis in the Japanese quail were fundamentally different from that of mammalian species, even from that in the man." In contrast, the classification described in this report is in general agreement with work on the drake (Clermont, 1958) and guinea-fowl (Aire et al., 1980) and is similar to the classification for mammals, especially primates (Clermont, 1963; Clermont \& Antar, 1973; Chowdhury \& Steinberger, 1976).

There are two noteworthy differences between the findings described in this report and those reported for the drake (Clermont, 1958) and guinea-fowl (Aire et al., 1980). Firstly, the lifespan of the leptotene primary spermatocytes in the quail is much shorter than that in the guinea-fowl (in which it is present at all stages of the cycle) and the drake (in which it is present in 7 stages of the 
(a)
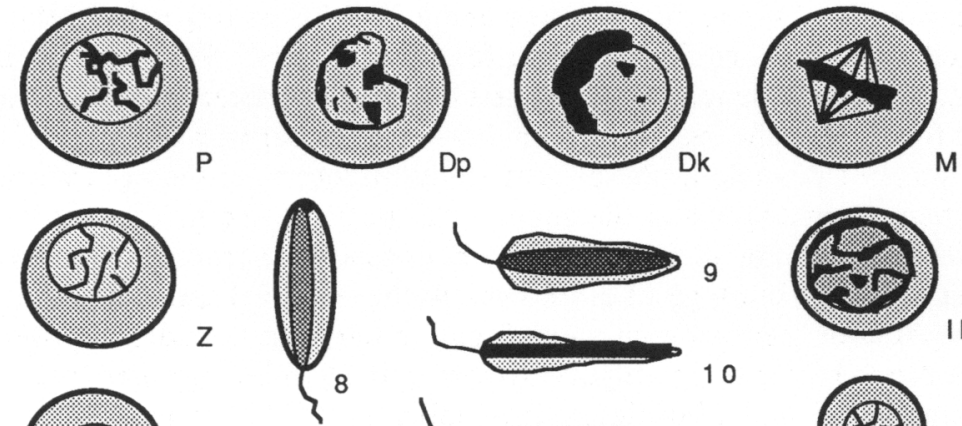

$\mathrm{Dp}$

$\mathrm{Dk}$
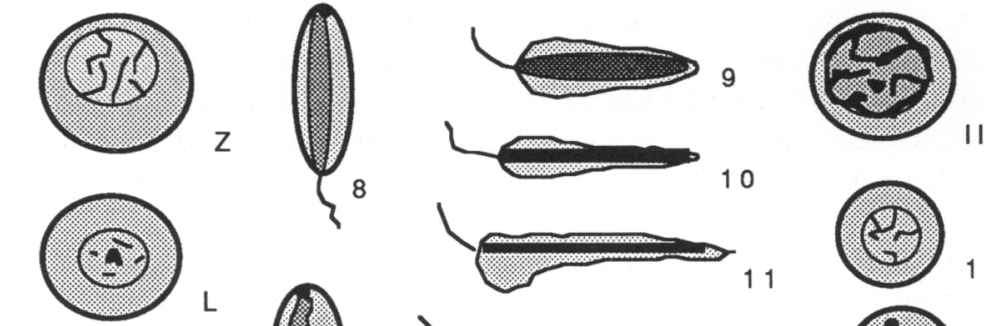

8
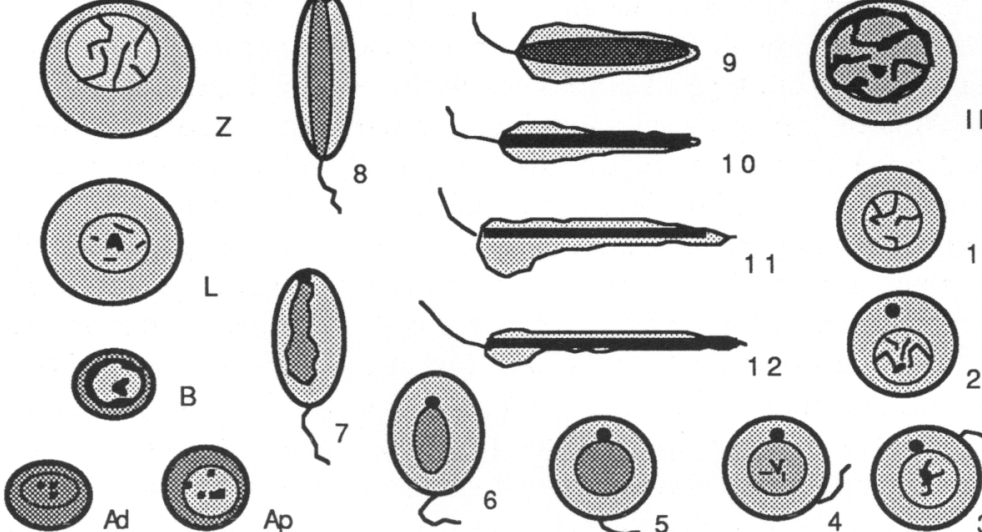

Ap
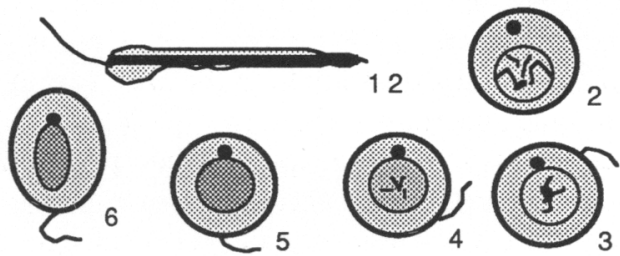

(b)

\begin{tabular}{|c|c|c|c|c|c|c|c|c|c|}
\hline 11 & 11 & 11 & 12 & 12 & & & & & \\
\hline 1 & 2 & 3 & 4 & 5 & 6 & 7 & 8 & 9 & 10 \\
\hline$P$ & $P$ & $P$ & $P$ & $P$ & $P$ & $D p$ & Dk & $M-A n$ & 11 \\
\hline B & B & B & L & Z & $P$ & $\mathrm{P}$ & $P$ & $\mathrm{P}$ & $\mathrm{P}$ \\
\hline $\mathrm{Ap}_{\mathrm{Ad}}$ & $\mathrm{Ap}_{\mathrm{Ad}}$ & $\mathrm{Ap}_{\mathrm{Ad}}$ & ${ }^{A p}{ }_{A d}$ & $\mathrm{Ap}_{\mathrm{Ad}}$ & $\mathrm{Ap}_{\mathrm{Ad}}$ & $\mathrm{Ap}^{\mathrm{B}} \mathrm{Ad}$ & Ap $\mathrm{BC}$ & $\mathrm{Ap}^{\mathrm{B}} \mathrm{Ad}$ & $\mathrm{Ap}^{\mathrm{B}} \mathrm{Ad}$ \\
\hline I & I I & III & I V & V & V I & VII & VIII & IX & $X$ \\
\hline
\end{tabular}

Fig. 12. The cycle of the seminiferous epithelium of Japanese quail showing (a) the main characteristics of the various types of germ cells (full length of tails not shown) and (b) germ cell associations of the 10 stages of the cycle. Ad, dark type A spermatogonia; Ap, pale type A spermatogonia; B, type B spermatogonia; L, leptotene primary spermatocytes; Z, zygotene primary spermatocytes; $\mathrm{P}$, pachytene primary spermatocytes; $\mathrm{Dp}$, diplotene primary spermatocytes; Dk, diakinesis of primary spermatocytes; M, Metaphase primary spermatocytes; An, anaphase primary spermatocytes; $1-12$, Step $1-$ Step 12 spermatids.

cycle). Secondly, the pachytene primary spermatocytes in the quail last much longer than in the drake and guinea-fowl.

The estimated duration of one cycle of the seminiferous epithelium in the quail (2.64 days) is much shorter than has been reported for mammals: an average of 11 days, and range from 6.7 days for the bank vole (Grocock \& Clarke, 1976) to 17.7 days for Bennett's wallaby (Setchell \& Carrick, 1973). The estimate in this study of the period between preleptotene primary spermatocytes and spermiation ( 8.54 days) is a little shorter than estimates by another method for the quail and some other birds. Amir et al. (1973) and Clulow \& Jones (1982) used an intraperitoneal injection of 
$\left[{ }^{3} \mathrm{H}\right]$ thymidine in the quail and found that the earliest labelled spermatozoa appeared in epididymal regions of the extragonadal sperm ducts 11 days and $9 \cdot 5-10 \cdot 5$ days respectively after the injection. A similar method was also used for domestic fowl (de Reviers, 1968) and the Barbary drake (Marchand et al., 1977; Marchand, 1979). The first labelled spermatozoa appeared in the ejaculate at 11-12 days in fowl and at the end of the 12th day in the Barbary drake.

Although it was not possible in the present study to determine the occurrence of the initial division of the stem spermatogonia in the quail, it was possible to estimate that it takes approximately 3.94 cycles (Fig. 12b), or 10.6 days, for spermatogenesis to proceed from the appearance of B spermatogonia at the end of Stage VI of the cycle to the release of spermatozoa at Stage V.

At least three types of spermatogonia were found in the present study; they were named dark type A, pale type A and type B spermatogonia following the terminology used by Clermont (1963), Clermont \& Antar (1973) and Chowdhury \& Steinberger (1975). Yamamoto et al. (1967) also described 3 types of spermatogonia in the quail and referred to them as type A, B and Intermediate spermatogonia. From their descriptions, the type A and type B spermatogonia correspond respectively to the pale type A and type B spermatogonia in this study. However, it is uncertain how their intermediate type spermatogonia relate to the dark type A spermatogonia described in this report.

There is also some uncertainty about the relationship between the dark type A and the pale type A cells described in this report. Our present interpretation is that the dark type A cells are most probably the stem cells in the quail, because they are always located on the basement membrane, and they are not as mitotically active as the pale type A cells. In some sections the pale type A cells were on the luminal side of the dark type A cells. Further studies are required to clarify the relationship of spermatogonia to one another and their renewal.

\section{References}

Aire, T.A., Olowo-olorun, M.O. \& Ayeni, J.S. (1980) The seminiferous epithelium in the guinea fowl Numida meleagris. Cell Tissue Res. 205, 319-325.

Amir, D., Braun-Eilon, B. \& Schindler, H. (1973) Passage and disappearance of labelled spermatozoa in the genital tract of the male Japanese quail in segregation or cohabitation. Annls Biol. anim. Biochim. Biophys. 13, 32 I-328.

Chowdhury, A.K. \& Steinberger, E. (1976) A study of germ cell morphology and duration of spermatogenic cycle in the baboon, Papio anubis. Anat. Rec. 185, $155-170$.

Clermont, Y. (1958) Structure de l'épithélium séminal et mode de renouvellement des spermatogonies chez le canard. Archs Anat. Microsc. Morph. 47, 47-66.

Clermont, Y. (1963) The cycle of seminiferous epithelium in man. Am. J. Anat. 112, 35-52.

Clermont, Y. (1972) Kinetics of spermatogenesis in mammals: seminiferous epithelium cycle and spermatogonial renewal. Physiol. Rev. 52, 189-236.

Clermont, Y. \& Antar, M. (1973) Duration of the cycle of the seminiferous epithelium and the spermatogonial renewal in the monkey Macaca arctoides. Am.J. Anat. 136, 153-166.

Clulow, J. \& Jones, R.C. (1982) Production, transport, maturation, storage and survival of spermatozoa in the male Japanese quail, Coturnix coturnix. J. Reprod. Fert. 64, 259-266.

de Reviers, M. (1968) Determination de la durée des processus spermatogénétiques chez le coq à l'aide de thymidine tritiee. Proc. 6th Int. Congr. Anim. Reprod., Paris 1, 183-185.

Grocock, C.A. \& Clarke, J.R. (1976) Duration of sper- matogenesis in the vole (Microtus agrestis) and bank vole (Clethrionomys glareolus). J. Reprod. Fert. 47, 133-135.

Gunawardana, V.K. (1977) Stages of spermatids in the domestic fowl: a light microscope study using Araldite sections. J. Anat. 123, 351-360.

Leblond, C.P. \& Clermont, Y. (1952) Spermatogenesis of rat, mouse, hamster and guinea pig as revealed by the periodic acid-fuchsin sulfurous acid technique. $A m$. J. Anat. 90, 167-215.

Marchand, C.-R. (1979) Contribution a l'étude comparée de la fonction testiculaire des canards de Barbarie (Cairina moschata L.) et hybride (du croisement Canard Pékin $\times$ Cane de Barbarie). Annls Sci. Univ. Fr. Comté 15, 3-63.

Marchand, C.-R., Gomot, L. \& de Reviers, M. (1977) Etude par autoradiographie et marquage á la thymidine tritièe de la durèe de la spermatogenèse du canard de barbarie (Cairina moschata L.). C. r. Séanc. Soc. Biol. 21, 927-931.

Ortavant, R. (1954) Etude des generations spermatogoniales chez le bélier. C. r. Séanc. Soc. Biol. 148, 1958-1961.

Roosen-Runge, E.C. \& Giesel, L.O. (1950) Quantitative studies on spermatogenesis in the albino rat. $A m$. J. Anat. 87, 1-23.

Setchell, B.P. (1982) Spermatogenesis and spermatozoa. In Reproduction in Mammals; Germ Cells and Fertilization, pp. 63-10I. Eds C. R. Austin \& R. V. Short. Cambridge University Press, Cambridge.

Setchell, B.P. \& Carrick, F.N. (1973) Spermatogenesis in some Australian marsupials. Aust. J. Zool. 21, $491-499$. 
Swierstra, E.E., Gebauer, M.R. \& Pickett, B.W. (1974) Reproductive physiology of the stallion. I. Spermatogenesis and testis composition. $J$. Reprod. Fert. 40, 113-123.

Yamamoto, S., Tamate, H. \& Itikawa, O. (1967) Morphological studies on the sexual maturation in the male Japanese quail (Coturnix coturnix japonica) 2. The germ cell types and cellular associations during spermatogenesis. Tohoku J. agric. Res. 18, 27-37.

Received 16 May 1989 